\title{
DROPLETS FROM THE PLANKTON NET XXVI. -NOTES ON THE EXCRETION IN EURHAMPHAEA VEXILLIGERA GEGENBAUR (CTENOPHORA)-
}

\author{
$\operatorname{AUTHOR}(\mathrm{S})$ : \\ Taniguchi, Tsuneya
}

CITATION:

Taniguchi, Tsuneya. DROPLETS FROM THE PLANKTON NET XXVI. -NOTES ON THE EXCRETION IN EURHAMPHAEA VEXILLIGERA GEGENBAUR (CTENOPHORA)-.

PUBLICATIONS OF THE SETO MARINE BIOLOGICAL LABORATORY 1975, 22(5): 321-321

ISSUE DATE:

1975-11-29

URL:

http://hdl.handle.net/2433/175897

RIGHT: 


\title{
DROPLETS FROM THE PLANKTON NET XXVI. NOTES ON THE EXGRETION IN EURHAMPHAEA VEXILLIGERA GEGENBAUR (GTENOPHORA)
}

\author{
Tsuneya TANIGUGHI \\ Tokyo Cinema Inc., Tokyo
}

The existence of numerous excretory glands containing a red fluid in the cetnophore, Eurhamphaea vexilligera Gegenbaur, and their possible function were referred to briefly in several lines on page 40 and again in detail on page 42 of A.G. Meyer's monograph "Ctenophores of the Atlantic coast of North America" (Carnegie Institution of Washington, 1912). The description in 13 lines on page 42 is quoted below to show what have been known about these structures.

There are numerous excretory pores along the courses of the meridional vessels (fig. 59, plate 11). These alternate with and open between the combs of cilia, and also open along the lines of the 4 meridional subventral canals over the oral lobes below the oral ends of the rows of combs. These pores contain a brilliant rosin-red oily substance which is cast out if the animal be handled roughly or be suddenly disturbed, forming a fluorescent-looking, rosin-red cloud in the water surrounding the ctenophore. When maintained in an aquarium the animal soon loses all of this red pigment and becomes quite transparent and inconspicuous, but in nature its 8 long rows of brilliant red dots render it most beautiful and conspicuous. We can only conjecture that this red substance is of an excretory nature and may possibly serve as a means of protection.

While I was engaged in taking the film "Marine Flowers", showing fascinating living features of coelenterates, that was to be presented under the sponsorship of the Matsushita Electric Industrial Co., Ltd. to the Expo '75 Okinawa, I had a chance, in January 1974, of making some observations on several specimens of this ctenophore in the sea near Enosima on the Pacific coast of Middle Japan. The excreted substance coloured the water just like a dilute solution of iodine tincture and gave my tongue a kind of bitter taste. Further, it was difficult to keep this ctenophore alive in a small tank as long as other lobateans that are devoid of excretory glands, because the former cast out the contents of excretory glands in the vessel and the excreted substance itself killed the animal in a very short time. Thus, it seems clear that the red substance in the glands is poisonous and, therefore, of a protective effect as supposed already in previous papers.

Hearty thanks are due to Dr. Y. Hirosaki and Prof. T. Tokioka for their help and advices given in making these observations and putting the present note.

Publ. Seto Mar. Biol. Lab., XXII (5), 321, 1975.

(Article 22) 